\title{
INFLUENCE OF KNOWLEDGE MANAGEMENT TO THE COMPETITIVENESS OF ENTERPRISES
}

\author{
Tatjana Simaškienè \\ Mykolas Romeris University \\ Ateities str. 20 LT-08303 Vilnius, Lithuania \\ Phone: (+370 8) 69949849 \\ E-mail: tatjana@ziniugausa.lt \\ Aistė Dromantaitè-Stancikienè \\ Mykolas Romeris University \\ Institute of Politics and Management \\ Ateities str. 20 LT-08303 Vilnius, Lithuania \\ Phone: (+370) 52740637 \\ E-mail: aistes@mruni.eu
}

Received on 4 July 2013; accepted on 10 December 2014

doi:10.13165/SMS-14-6-3-07

\begin{abstract}
In this article, influence of Knowledge Management system to the Competitive advantage is analyzed. Correlation between Knowledge Management and Competitive advantage investigation is made by Strategic Management system. Analyzing scientific literature, given Knowledge and Knowledge Management conceptions are systematized and their evaluation is made with regard to Competitive advantage. When performing the analysis, it was noticed that Knowledge Management can help to make better company activity's efficiency, this way company can achieve succsessful Competitive advantage. But if we want to get utility of Knowledge Management, it is necessary to harmonize all Knowledge Management aspects, depending on context
\end{abstract}


of company's activity. Searching for the answer how succsessfully realize iniciation of Knowledge Management and to give the company Competitive advantage, during this investigation a model of theoretical Knowledge Management realization was designed.

Keywords: Strategic Management, Resource standpoint, Knowledge, Knowledge Management, Comptetitive advantage.

JEL classification: L20-Firm objectives, Organization, and Behavior.

\section{Introduction}

Modern economy is characterized by quick and impulsive changes, globalization and savage competition. Old economy was characterized by high level industrialization and production organization, each company had three Competitive advantage strategy options: leader costs, leader niche and differentiation strategy ${ }^{1}$. Company, which was trying to live out in such difficult conditions, had to find invariably modern adaptation ways and abilities to compete in a competitive surrounding. In such surrounding, which quickly changes, company has the resource management problem. That is why modern economy's angular stone uses effective material and nonmaterial knowledge resources in order to reach Competitive advantage.

As say scientists (Zuboff, Maksim and others), state, the newest economy gives more expectancies to live out companies, which are projecting and using the information, knowledge and resource controlling systems and networks, which help rationally control material and nonmaterial resources ${ }^{2}$.

Knowledge Management of recent 10 years have progressed from embryo till more and more accepted scientific area, but the most part of Knowledge Management works has a describing character, they are directed to the definition creation and integration to the existing describings. That is why there are no comparatively many investigations (the most of them reviews), which pay their attention to the Knowledge Management from other organizational factors viewpoint. Lithuanian scientists are also reviewed in this article $3,4,6$.

1 Porter, M. Competitive Advantage: creating and sustaining superior performance: with a new introduction. - New York: Simon and Schuster, 1998.

2 Zuboff, Sh. and Maxim, J. The Support Economy: why corporations are failing indi-viduals and the next episode of capitalism. - New York: Viking 2002.

3 Melnikas, B., Smaliukienè, R., Strateginis valdymas, Mokomoji knyga., Vilnius, Generolo Jono Žemaičio Lietuvos karo akademija, 2007.

4 Savickienė, I. , Pukelis, K. Institucinis studijų kokybės vertinimas: dimensijos, kriterijai ir rodikliai // Aukštojo mokslo kokybė, 2004, 1:26-37.

5 Beniušienè, I. and Svirskienè, G. Konkurencoingums: teorinis aspektas // Ekonomika ir vadyba: aktualijos ir perspektyvos. 2008. Nr. 4 (13): 32-40. Raudeliūnienè, J. Žinių vadyba, Mokomoji knyga. - Vilnius; Technika, 2012. 
Also this theme in many ways was analysed by many foreign scientists, such as Porter $^{7}$, Zuboff, Maksim ${ }^{8}$, Enz $^{9}$, Lamb ${ }^{10}$, Nag et al. ${ }^{11}$, Amit, Schoemaker ${ }^{12}$, Jackson, Hitt, DeNisi ${ }^{13}$, Fahy, Smithee ${ }^{14}$, Thompson and Martin ${ }^{15}$, Jashapara ${ }^{16}$, Walters et al. ${ }^{17}$, Davenport and Prusak ${ }^{18}$, Skyrme ${ }^{19}$, Newell et al. ${ }^{20}$, Wilson ${ }^{21}$, Shannak ${ }^{22}$, Chua and $\mathrm{Lam}^{23}$, Osborne and Gaebler ${ }^{24}$.

An essential background, which gave an impulse to Knowledge Management studies, is creating, putting, saving and giving very important knowledge. In this way organization acivity becomes perfect, but to find it the authors missed empirical proofs.

7 Porter, M. Competitive Advantage: Creating and Sustaining Superior Performance. - New York: Free Press, 1985. Porter, M. Competitive Advantage: creating and sustaining superior performance: with a new introduction. - New York: Simon and Schuster, 1998.

8 Zuboff, Sh. and Maxim, J., supra note 2.

9 Enz, C. A. Hospitality Strategic Management: concepts and cases. - New Jersey John Wiley and Sons, 2009.

10 Lamb, R. B. Competitive Strategic Management. - Englewood Cliffs, NJ: Prentice Hall, 1984.

11 Nag, R., Hambrick, D. C. and Chen, J. Ch. What is Strategic Management Really? Inductive Derivation of a Consensus definition of the Field. // Strategic Management Journal, 2007, vol. 28, no. 9, p. 935-955.

12 Amit, R. and Schoemaker, P. J. H. Strategic assets and organizational rent, Strategic Management Journal, 1993, vol. 14, no. 1, 33-46 p.[interactive] [accessed 04 -06-2013] http:// business.illinois.edu/josephm/BA545_Fall\%202011/S11/Amit\%20and\%20Schoemaker\%20 (1993).pdf.

13 Jackson, S. E., Hitt, M. A. and DeNisi, A. S.(eds.) Managing knowledge for sustained competitive advantage: designing strategies for effective human resource management: The Organizational Frontiers, 1st edtn, - San Francisco: Jossey-Bass, 2003.

14 Fahy, J. and Smithee, A. Strategic marketing and the Resource Based view of the Firm. 1999.URL.: http://www.amsreview.org/articles/fahy10-1999.pdf.

15 Thompson, J. and Martin, F. Strategic Management. -London: Cengage Learning EMEA 2010.

16 Jashapara, A. Knowledge Management: an integrated approach. -Edinburgh: Pearson Education, 2004.

17 Walters, D., Halliday, M. and Glaser S. Creating value in the new economy. Management Decision. - 2002,vol. 40, No. 8, p. 775-781.

18 Davenport, Th.H. and Prusak, L. Working Knowledge: How Organizations Manage what They Know. - Boston:Harvard Business School Press, 2000.

19 Skyrme, D. J. Knowledge Networking: Creating the Collaborative Enterprise. - Oxford: Butterworth-Heinemann, 1999.

20 Newell S., Robertson M, Scarbrough H, Swan J. Managing Knowledge Work. London: Palgrave McMillan, 2002.

21 Wilson, T. D. The nonsense of „knowledge management“. Information Research, 2002, vol. 8, no. 1. [interactive] [accessed 04-06-2013] http://informationr.net/ir/8-1/paper144.html.

22 Shannak, R. O. Measuring Knowledge Management Performance // European Journal of Scientific Research. 2009. vol. 35, no. 2, - p. 242.

23 Chua, A. and Lam, W. Why KM projects fail: a multi-case analysis // Journal of Knowledge Management, 2005, vol. 9, no. 3, pp. 6-17.

24 Osborne, D. and Gaebler, T. Reinventing Government. - New York: Addison Wesley, Plume 1993. 
The aim of this investigation is to fill in and remove all fixed failings and assemble practical empirical proofs about connection between Knowledge Management and Competitive advantage, and to find method, which will help to secure gain of Knowledge Management for Competitive advantage.

The aim of this article through investigating theoretical sources, to analyze conception of Knowledge Management and to define its main elements, to analyze Knowledge Management and Competitive advantage relation in order to give understanding how and in which way Knowledge Management influences the company activity's efficiency and how it forms sustainable Competitive advantage. In order to continue the study, qualitative investigation will be given in another article, and theory in this article is based on it.

Research methodology is determined in accordance with the principal of pragmatism, such direction of this work is chosen - Knowledge Management accordingly with inductive approach is shown like strategic resource and as a Competitive advantage tool. Because this work was restricted by volume and time, cross-section method was chosen. Primary data was collected through semistandardized interview. As the interview method was characterized by particular flexibility, enough information was collected. All collected information was analyzed using a thematic scientific literature analysis.

\section{Strategic management concept analysis}

Strategic management influence growth can be associated with the competitive environmental development, transport and communication technologies, global markets modernization and technological advancements ${ }^{25}$. Strategy is defined as the organization's long-term position, with decisions made to benefit the organization willing and able to provide users, joining and aligning their operational systems and finding ways to recover effectively long-term investments ${ }^{26}$.

According to Lamb ${ }^{27}$, strategic management is a continuous process, which estimates, controls, implements re-evaluation of the objectives and strategies in order to catch up and overtake the current and potential competitors.

Essentially, strategic management is a set of initiatives, which describe how to use the available resources in order to increase the efficiency of the company in the context of the market ${ }^{28}$.

The process of strategic management is focused on the following key questions to a company:

Enz, C. A., supra note 9.

26 Melnikas, B., Smaliukienè, R., supra note 3.

27 Lamb, R. B., supra note 10.

28 Nag, R., Hambrick, D. C. and Chen, J. Ch., supra note 11. 
- Which markets the company has to compete? What are the ways to compete in selected markets in order to create a competitive advantage? How to keep achieved competitive advantage sustainable and hard to approach by competitors?

It is evident that in answering these questions, both practitioners and researchers differently understand competitive advantage and provide different answers. However, by grouping all possible answers three strategic management options are identified:

- Traditional option - traditional entity (company's) strategy;

- Intangible and / or intangible resources strategy;

- Interested parties 'strategy - it's an approach, that interprets the company as a network relationship of interested parties.

This article uses as a starting point the resource-based approach, which deals with the company as a whole consisting of resources and skills whose competitive advantage depends on the rare (imitated) resource management ${ }^{29},{ }^{30}$. Resources in this context are perceived as a whole of the tangible and intangible assets and skills ${ }^{31}$.

Resource-based approach can be considered the foundations of competitive advantage theory. competitive advantage theory focuses on the mode of achieving and maintaining competitive advantage. Resource-based approach explains that competitive advantage is effective strategic resource, which has value and is complex to simulate, manage and use. Therefore, resource-based approach supports management of the company in accordance with the strategic decisions, which create or formulate ways to use the company's most important strategic resources in order to increase economic returns ${ }^{32}$.

In this sense, resources are strategically important for the competitive advantage. In other words, the resource value and uniqueness makes them „strategic“ resources. There are no predefined parameters to specify what do resources mean, because these parameters are different, and depend entirely on the context. However, there are signs, which describe which resource is strategic. Thompson and Martin ${ }^{33}$ provide general resource values accordingly to audit principles, specifically:

- Competitive advantage - is the value of resources and the competitiveness of the relative comparison;

- Replication limitation - influences resource growth, in case of increasing restrictions to restore or imitate;

- Durability - describes how much time can be maintained in the first two above listed characteristics;

- Convertibility - determines whether it is possible to replace the outdated resources by alternative ones;

29 Amit, R. and Schoemaker, P. J. H., supra note 12.

30 Jackson, S. E., Hitt, M. A. and DeNisi, A. S., supra note 13.

31 Thompson, J. and Martin F. Strategic Management. - London:Cengage Learning . EMEA 2010.

32 Fahy, J. and Smithee, A., supra note 14.

33 Thompson, J. and Martin, F., supra note 15. 
- Individuality - an expression, when company "controls" resources and provides profit, differently from resources managed by the company.

In summary, the resource- based strategic approach, which analyses company as a resource, skills, abilities, knowledge management as a whole, become key in building an exclusive competitive advantage features ${ }^{34}$.

\section{Knowledge concept analysis in the context of scientific management}

Knowledge is difficult to understand in the concept of discussions. Knowledge concept evaluation depends on the context, in which it is examined. But whatever the context for different types of knowledge, the majority of scientists ${ }^{35}$ agree, that knowledge is a certain collected information, which is used for achieving estimated goals.

Knowledge is the new generation of intangible resource, it is completely different from the traditional resource, such as manufacturing facilities or industrial technology. However, it equally and may be more effectively influences the efficiency of the company.

The intellectual form of capital, knowledge characterizes properties of strategic resources in accord with Thompson and Martin ${ }^{36}$ described principles. Strategically important knowledge makes them unique, because they are difficult to replicate and to reproduce in their abstract nature. Also knowledge is a lasting resource, protected by the company's personnel thoughts or systems, and it can be assembled and gathered.

According to Walters et $\mathrm{al}^{37}$, there exists another interesting feature of knowledge - that knowledge, being a strategic resource is the only resource, which is increasing when it is being used, while the others, when are used, deplete. This feature of knowledge further increases its value as a strategic resource. We can say that knowledge is a strategic resource, which can be used for competitive advantage. However, just possessing a resource, the fact in itself doesn't affect the level of competitiveness, nor can possession of knowledge affect this level. Therefore, knowledge as an important strategic resource, must be effectively managed, that company would receive benefit from the ability to provide added value, to nourish and support competitive advantage of the company. 


\section{Knowledge management definition and its key elements}

Knowledge management is an ambitious discipline, included in the generally accepted range of subjects, but due to its novelty it isn't fully defined and this leads to some confusion regarding the concept of discussion. This uncertainty arises because knowledge management discipline consists of a variety of scientific disciplines, such as anthropology, strategy, information science, computer science, economics, human resource management, psychology, philosophy, sociology, management science, synthesis of compounds. While knowledge management is a very rich area, it is researched of a variety of complementary and scientific perspectives.

Knowledge management multi-property features have many definitions, which stem from the foundational disciplines. In order to clarify the concept of knowledge management, it is appropriate to give a few of basic approaches to its definitions.

Davenport \& Prusak ${ }^{38}$ define knowledge management as a process, which is focused on company's resources with an emphasis on integration practices of information systems and human resource management. This definition is based on information, education and perspective of human resource management integration. Skyrme ${ }^{39}$ describes knowledge management as an explicit and systematic company's management and its vital knowledge and knowledge creation, accumulation, organization, dissemination and use processes in order to achieve management goals. This definition arises from the information science perspective.

Newell and others ${ }^{40}$ define knowledge management as a set of knowledge management processes that help company to tap into knowledge assets in a changing environment in order to attract regular innovations. This definition is derived from the strategic perspective. Knowledge management helps the company to create, collect, organize, share, analyze, update and use knowledge as rationally managed resources, it lets the company adapt to the changes and compete successfully in the market. In conclusion, knowledge management is an organization's strategic process, which is directed to strategic capabilities developing, enabling to deal with turbulence in the business environment, which lastly helps to achieve competitive advantage. This knowledge management definition is based on strategic approach.

Regarding the nature of knowledge, different aspects of knowledge management definition and knowledge management formation, it is necessary to describe the essential knowledge management processes. Jashapara ${ }^{41}$ describes knowledge management cycle as a learning company`s effective synthesis of knowledge creation, organization, sharing and use, which results in improved intellectual capital and increases of the productivity of the company which further lead to the competitive advantage of the company.

38 Davenport, Th.H. and Prusak, L., supra note 18.

39 Skyrme, D. J., supra note 19.

40 Newell S., Robertson M, Scarbrough H, Swan J., supra note 20.

41 Jashapara, A., supra note 16. 
Knowledge management cycle consists of 4 main processes:

1) The first process involves knowledge creation (also known as accumulation, updating or invention), which takes place every day in organizations, using a variety of methods. Knowledge creation is an endless process, which combines new ideas, new theoretical and methodological aspects of the search and bring them together into a new whole system ${ }^{42}$.

2) The second process involves the knowledge of organization (management). This is knowledge storage, recording and sorting, it easyfies recovering or receiving knowledge if necessary.

3) The third process knowledge sharing process (also known as sharing and dissemination). This is a mutual action, in which knowledge is distributed and spread between individuals through mechanical and other than mechanical databases. Most of knowledge management success depends on the knowledge sharing and exchanges. In other words, knowledge management cycle depends entirely on the ability of people to exchange and share knowledge. In this part company's culture influence to the knowledge transfer is visible.

4) The fourth process is use of knowledge itself, which is connected with deals with the efficient ,functional' knowledge, in order to solve the problems, to manage processes and to create a good working environment for the creation of knowledge (motivation, the importance of working environment). According to Raudeliūniené $\dot{e}^{43}$, knowledge is defined as the process of using knowledge management implementation phase, where knowledge is transformed into concrete results. Knowledge using cycle is knowledge transfer in a finite service or product ${ }^{44}$.

Knowledge management for its multidisciplinary origin, as discussed above, is estimated from different points of view, that's why different scientists have different approaches to knowledge management essence. Some publications about knowledge management analyze information systems, that's why an impression may be formed that knowledge management is equal to information management. Other sources emphasize more intellectual resources creation and diffusion, which suggests that knowledge management is an intellectual resource management.

Therefore, while analyzing knowledge management, it is useful to identify knowledge management dimensions. Dimension is a feature, which is very important for the estimation of the quality of the object and to some extent determines conditions of existence, which are necessary for the measured object ${ }^{45}$.

Knowledge management framework components by Jashapara ${ }^{46}$ are:

- Strategy - intellectual capital management strategy optimization in order to optimize the company's activities;

- Culture - company culture phenomenon, that significantly reveals in implementing and managing alterations;

\footnotetext{
42 Jashapara, A., supra note 16.

43 Raudeliūnienè, J., supra note 6.

44 Jashapara, A., supra note 16.

45 Savickienè, I. , Pukelis, K., supra note 4.

46 Jashapara, A., supra note 16.
} 
- Company's learning - the company level of knowledge search, dissemination and use of process capability;

- Systems and technologies - systems and tools for practical knowledge management; knowledge management systems that support knowledge management and support business functions ${ }^{47}$.

From knowledge management components three essential knowledge management dimensions are singled out: people, processes and technologies.

The first dimension is people. Whereas knowledge management is primarily based on people, people's willingness to participate in knowledge management system is the most important task of knowledge management. This preparation for knowledge management system depends on the company culture (including values and behaviors), which is the most important factor in knowledge management. It is important for the company to support and encourage continuous learning and knowledge sharing culture, motivate and encourage people to create, share and apply knowledge; maintain openness, mutual respect and support for culture.

The second dimension is processes. In order to improve the exchange of knowledge, company must adapt internal processes, and sometimes even the whole enterprise structure. For example, if a company is structured in such a way, that its different parts compete for resources, then it will be probably a barrier to knowledge sharing in process. Reviewing the many aspects of how processes in organization are functioning, it is necessary to find processes, that constitute an obstacle to the knowledge management flow. They need to be modified or replaced by other processes that encourage or motivate people to create, modify, and use knowledge.

The third dimension is technologies. A common belief is that knowledge management is just technologies. We suppose, the intranet technology, which is connecting people via e-mail and is generating information databases is often a very important knowledge management assurance. Intranet technology helps to connect people for information gathering and with one another. However, this is not the most important. Most important, in use of technologies are people and processes, otherwise technologies can't be used.

These three components scientists often visually compared with a tripod - if at least one leg is not available, a tripod will collapse. However, a lame feature in people's dimension is taken more seriously than in other dimensions. Company's particular attention should be given to the knowledge, facilitating creation of culture, which shapes people's attitudes to change and acceptance of knowledge management systems. That's why a person is one of knowledge management component.

With respect to analyzed theory, the concept of knowledge management in the context of this study is defined as a collective learning process, related to the search of tacit and explicit knowledge, its transfer and utilization ${ }^{48}$. In this process, a set of knowledge features is identified or developed, assembled, stored, updated and 
pooled in order to improve the company's performance. When these processes are effective and sustainable, the company can take advantage of the potential benefits of knowledge management, thus creating a competitive advantage.

\section{Knowledge management, based on competitive advantage}

There is no common approach to competitiveness globally. This is because competitiveness is a particularly complex category, and not a simple situation or condition that is measured by one or more parameters.

Competitiveness of the company is directly linked to the company's ability to respond quickly to the urgent changes in the market and maintain their position in it. It's often determined by the entity (state, companies, groups or individuals) the economic and social welfare, prestige. Too little competitiveness can be a big loss, shock or even the cause of the collapse.

Porter $^{49}$ stated, that there are two basic types of a competitive advantage of the company - low cost or differentiation, which in combination with a specific business rate - the target market segments range - allow you to create three general strategies for the company to achieve higher than average performance: cost leader, differentiation and focus, or scale reduction.

Cost leader - such competitive strategy of a company, in essence, is the ability to produce the right quality product or service cheaper than its competitors, which enables to realize a lower cost than other market participants. Such strategy is achieved in consequence of production economies with sufficient expertise and investment in technology sphere.

Differentiation competitiveness strategy -is when company's products or services stand out from its competitors' in certain properties, which customers treat as better products and services than the relevant competitors' products. In this way the company produces or provides unique products and services. The company can offer high quality, good service at the right price.

Focusing - is the company's strategy on competitiveness, which requires attention to a focus on small market segments. The company can focus on certain groups of users, or certain areas ${ }^{50}$.

An enterprise for itself chooses how to provide services or goods to your customers and clients. While receiving the desired goods and services at the right price, company customers will receive the required value, for good quality. Consequently, the company's competitive advantage derives from the value, which company can provide for its customers ${ }^{51}$. This value can be an equivalent product in the form of lower price, or unique, but expensive product or service form. This

49 Porter, M. Competitive Advantage: creating and sustaining superior performance: with a new introduction. - New York: Simon and Schuster, 1998.

$50 \quad$ Ibid.

51 Ibid. 
advantage over the competition means, that the company has a competitive advantage over your opponents in the market. Thus providing the maximum value is increasing competitive advantage, covering the sequence of added-value activities, as a result is formed company activities circuit. This activity chain aims to provide greater value, which will be recoded into a competitive advantage and profit margin ${ }^{52}$. Resourcebased strategy approach provides the company with a valuable, rare and difficult to replicate resource is successfully used for high-value aims.

Basically competitiveness - is the company's advancement, more than competitors' advancement achieved by using value-added processes and application of differentiation, cost or leadership niche strategies ${ }^{53}$.The advantage is displayed in increasing revenue, greater customer satisfaction, increased customer volume, improvement of brand image and other tuned methods.

Knowledge management, as we found out, is a set of processes, associated with retrieval of tacit and explicit knowledge, transfer and use of knowledge in order to increase the company's intellectual capital and business performance ${ }^{54}$. According to Raudeliūniené $\dot{e}^{55}$, the essential purpose of knowledge management is to make personnel intellectual knowledge of sustainable competitive advantage, i.e. effective targeting of intellectual capital in the right direction. Long-term sustainable competitive advantage for organizations is associated with the use of knowledge management systems and resources (which have no competitors) enhancement.

Competitive advantage, based on knowledge management is knowledge management, processes and business initiatives to gain an advantage over competitors. This advantage can be achieved through cost leadership, market leadership in a niche and differentiation strategies using knowledge management as a critical factor.

From discussed theoretical material context, we can conclude, that knowledge management is a strategy, a company culture, company's learning, systems and technology interaction with people, processes and technologies in order to increase the company's intellectual capital and business performance.

\section{Knowledge management in enterprises}

In this part of the article theoretical analysis of what is known about knowledge management is discussed. The analysis reveals new insights into knowledge management and competitive advantage interfaces. The analysis is based on the theoretical part of the theoretical and conceptual frame.

The study aimed to actualize the target, i. e. to explore relation between knowledge management and competitive advantage in practical environment and to

53 Ibid.

54 Jashapara, A., supra note 16.

55 Raudeliūnienè, J., supra note 6. 
analyze, how knowledge management influences competitive advantage. Thus, after discussing relationship, of knowledge management and competitive advantage, after examination how knowledge management influences competitive advantage and after data analysis and interpretation, were made following generalizations:

- Knowledge management - is a methodology, that combines technological information systems and knowledge management aspects, enables knowledge to be used in its proper context, assists in the strategic management of intellectual property and in achieving competitive advantage and implementation of the company's goals, while making it an effective framework in order to facilitate staff's daily work.

- Knowledge management - is a multidisciplinary field, which can be analyzed from a variety of complementary treatment perspectives. This shows the complexity of knowledge management, and proves, that there are no generally accepted theories, appropriat to define this phenomenon and identify the fundamental lack of theoretical and empirical material. On the other hand, this area provides a variety of perspectives and knowledge management advantages; that makes it a powerful company's competitiveness-enhancing measure and undermines the assertion, that knowledge management resource is useless.

- Knowledge management - is a mix of three elements: people, processes and technologies. This leads to the understanding, that a lot of knowledge management initiatives that focus on one area, collapse, because the following aspects of diversity are ignored. Knowledge management is not a plethora of options, as stated ${ }^{56}$, and there are many aspects of one sphere. This is another argument, which provides knowledge management complexity, and helps to understand why Davenport and Prusak ${ }^{57}$ noted many failed knowledge management initiatives, which were focused on one area. It is important to stress that in order to create a sustainable knowledge management system, it's necessary coordinate harmoniously all aspects of knowledge management in creation process and according to the business context. Knowledge management - is a set of knowledge management processes. These processes include knowledge in a given environment, the collection, storage, distribution and use. An effective knowledge collection, storage, distribution and use secure efficient knowledge management system's presence. Only an effective knowledge management can transform company's activities to the efficient and secure competitive advantage.

Knowledge exchange is knowledge management process, by which knowledge is disseminated, that becomes available to the circle of people interested in. This process of knowledge storage and accessibility provides to the enterprise transparency and makes it more understandable to its employees. The most important feature of the process of knowledge sharing is accessibility. Knowledge must not only be stored, organized and divided, but it can also be easily made available to people, who intend to use it. If knowledge is managed, but inaccessible, it loses all importance and can't 
provide benefits. This is because resources, based on the description of resources, make profit only when are used in enterprise. Equally, it is important, that knowledge opening procedure be short and as simple as possible. In extreme circumstances, when a decision must be taken within a very short time, the simplicity and brevity of the procedure helps quickly to get the information and knowledge. Therefore, the most appropriate and expeditious knowledge opening speed is an important consideration in determining the level of success of the company in the market. Timely decision could significantly change the market players' positions, to influence new formations and origination of the leadership. Uptime and its speed are also determined by the transparency of the company, because knowledge and information are easily accessible, which leads to openness, through systematic reporting procedures to the responsibility of the employees.

Technology and system infrastructure are necessary for successful knowledge management system construction and can't be forgotten. However, the technology component of knowledge management is not required, because it's not an end in itself, but a tool, that helps people to manage knowledge. It should also be noted, that technological systems, directed to supporting knowledge management processes are as effective, as effectively they are managed by people. People are essential to knowledge management initiative, because they are the ones, who carry out knowledge management tasks. Technologies for knowledge management support may be the most advanced, but if there are no people who participate in knowledge management processes, then all efforts are in vain.

To ensure the success of knowledge management initiatives, general company personnel and management efforts for preparing for the implementation of the project are necessary. Preparing of workers for the introduction of specific measures isn't possible, the company doesn't have the values, norms and procedures to help in preparing for such changes. Joint efforts and universal preparation for implementation of the project can appear only in such cases, if the company's culture plays an important role in shaping the open, ready to change company.

Knowledge management initiative as a joint effort, which forms the company's culture, is shaped by people and their actions. Environment of the company must be open to change, so it's very important for knowledge management initiatives support, which is derived from the company's culture, from people, who shape it. The company's culture is a factor, which helps to prepare for the changes, which will determine the company's openness to knowledge exchange. Therefore, workers cooperation and exchange of knowledge should be encouraged in the company, this leads to mutual support, trust and becomes a company's value.

In summary, it can be said, that knowledge management is a summ of people, processes and technologies, that support knowledge creation, collection, storage, transfer and use. People are the main component of knowledge management, because only they can perform knowledge management processes through technology. 


\section{Theoretical framework for knowledge management implementation}

In order to illustrate how knowledge management as a resource can be used in getting competitive advantage and by using theoretical analysis of scientific material as well as the results obtained during reviewing the concept the following knowledge implementation model was constructed (see Figure 1).

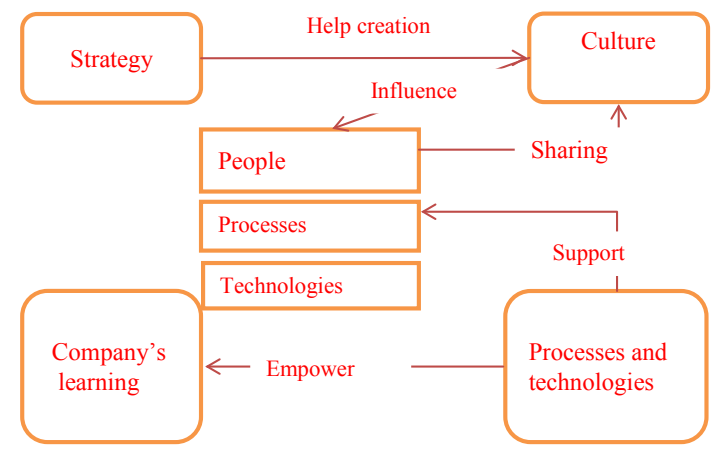

Source: adopted from Jashapara (2004) and enhanced with own research results.

Figure 1. Knowledge management implementation model

In knowledge management implementation model (see Figure 1) it is attempted to visualize, how to implement knowledge management system in the company; that would help to achieve a competitive advantage. This interview is based on the analysis of information, obtained theoretical knowledge management dimensions and aspects of the model results by Jashapara ${ }^{58}$. Based on this model, it can be said, that in order to ensure successful implementation of knowledge management initiatives, company has to form:

- Company's strategy, which knowledge management estimates as a strategic resource and understands the profit of successful knowledge management initiatives. While the strategy is in process of preparation it has to plan for the knowledge management opportunities offered in order to gain a competitive advantage. Such strategy is formed by an open company's culture only; a culture, that fosters openness, transparency and willingness to change.

- Company's culture has to motivate and support knowledge management initiative, and thus the company has a chance to complete a successful knowledge management initiative; 
- Company's learning promotes processes of knowledge searching, collecting, sharing, and use.

- $\quad$ Systems and technologies support organizational learning and knowledge management processes.

When knowledge management project is designed by focusing on all four knowledge management aspects and is focusing on pre-set goals makes the initiative practicable.

It is also important to ensure the company's personnel (human) support. If you ignored the workers' motivation and readiness for knowledge management system implementation, all the initiative becomes doomed to fail. The system can't run by itself, also the strategy can't be established by itself nor implemented by itself, the culture can't exist for itself, the company's learning doesn't exist without training participants; all of these processes depend on an individual and only the individual can carry them out. Therefore, it's very important to ensure a unified whole staff support and interest to knowledge management system. Only then, the company can expect to have benefit from knowledge management.

\section{Ensuring benefits of knowledge management in enterprises}

It can be considered that one of the most important and equally challenging aspects is the ability to ensure that knowledge management actually provides benefits to the company. The most effective way to find out if knowledge management is proper is to measure it. Although knowledge management contributes to the companies promising benefits it has to be universally understood and accepted.

It is not wise to recognize the investment to knowledge management benefits without hard evidence. Knowledge management and its impact measurement is usually a matter of debate ${ }^{59}$. This debate stems from the fact that knowledge is abstract and difficult to separate from variables, its measurement is very difficult. One of the claims of knowledge management performance, according to Ibrahim and Reid ${ }^{60}$, is that it is difficult to determine on how knowledge management is „valuable. " That is why no less difficult is to find a mechanism, which will be able to measure knowledge management value. This highlights earlier statement, that knowledge management lacks potency to show and define the relationship between knowledge management and its potential benefits clearly. The unclear relationship between knowledge management and enterprise performance and its competitive advantage support the view, that knowledge management is just a fad, and not a true management practice.

In recent years, however, opinions about knowledge management existence are levering because new facts in the field of knowledge management come to view. This furthers knowledge management transformation to the widely applicable

59 Shannak, R. O., supra note 22.

60 Ibrahim, F., Reid,V. Unpacking Knowledge Management: Management Fad or Real Business Practice? Enterprise Risk Management. - North America, 2010. 
management practices. The result of this research is make another step in this direction, which helps to explain yet unanswered questions and to deny knowledge management criticism.

In this research an idea was brought forward of how to make connections between knowledge management and clear and understandable advantages. This is achieved through previously discussed knowledge management implementation model in combination with advisability and measurement criteria.

Knowledge management initiative should be introduced reasonably and purposely, and in respect of specific action plan. Knowledge management initiatives should be based on pre-raised objects and targets. The result with the help of knowledge management must be planned clearly and concretely, it should be given proper attention and provided with an action plan in order to achieve this result. According to Chua and $\mathrm{Lam}^{61}$, most knowledge management projects failure reasons are: bad management and control, inadequate support for the execution and unclear aims. Objective knowledge management initiative eliminates these obstacles and provides a reliable chance to achieve a potential benefit. Therefore, we can say, that expediency is the first premise for successful knowledge management initiatives.

Measurement is related to the directivity, if initiative is focused and directed towards a specific goal, it allows, taking into account the objectives set, to assess the real benefits of the initiative.

For example, if knowledge management initiative is focused on the problem of operating costs in order to reduce them, the company firstly has to analyze operating costs before implementation of the knowledge management project. This analysis must be clear and concise, realistic and fit the company's context, and most importantly, to assess the actual cost of the problem. In other words, you need to find the problem financial expression, precisely the problem "price.“

With the problem financial expression, it becomes easy to measure the impact of knowledge management - it's enough to assess change of "price" issue. Measurement allows understanding of what is being measured. In order to perform accurate measurements it is necessary to have detailed understanding of what you measure. In addition, the company can't manage what you can't measure. Measurement supports resource management. This process was excellently described by Osborne and Gaebler ${ }^{62}$ : „If you don't measure results, you can't separate success from failure. If you can't see success, you are unable to reward it. If you can't reward success, you're probably award failure. If you can't see failure, you can't learn from it. And if you can't recognize failure, you can't correct it."

Use of expediency and measurement principles, implementing knowledge management initiatives can be beneficial to the company which intends to improve operational efficiency and achieve competitive advantage. knowledge management system should be introduced not for their own sake, but to contribute to achieving common business goals.

61 Chua, A. and Lam, W., supra note 23.

62 Osborne, D. and Gaebler, T., supra note 24. 
The assessment also can provide a lot of important things. Measurement function by definition focuses on the way the measured item is expressed. When attention is focused on the activities, that are changing, interest to these activities is enhanced, and when such interest is formed, the chances that these activities will succeed, increase.

Another importance of measuring is understanding that by measuring an item increases people's interaction with the measured item. In order to understand whether the situation is improving after the introduction of the initiative, it is necessary to gain more insight into the situational context and concepts. Uninterrupted measurement inevitably leads to a deeper understanding of the measured entity.

In addition, it is important is fact that that can't be measured can't be managed ${ }^{63}$. Measuring enriches the quality of decision-making process and supports the company's resources. The information, gathered during the measurement process, can be used in making management decisions in order to change and improve certain organizational processes.

These statements, of course, aren't quite flawless. First of all, not all problems are easily transformed into a financial plane. If the understanding of problem is wrong, the observed change will be most likely negative as well. However, this doesn't mean, that the method is completely unsuitable for use, and it reflects the assumption, that the initial and final evaluations should be properly arranged, so that the measurements will be correct. There are also other factors, which must be considered, using principles of measurement.

The modes of action are preliminary, their expedience and measurement require further consideration in order to optimize them, so this work is just the first step in this direction, and can be further developed.

\section{Conclusion}

The intention of this article was to realize the goal: in practical environment to explore relationship between knowledge management and competitive advantage and to analyze, how knowledge management influences competitive advantage. Thus, after discussing relationship of knowledge management and competitive advantage, knowledge management effects on competitive advantage were reviewed and after providing a model, that helps to ensure knowledge management effects on business competitiveness, also after analysing data and interpretation, the following conclusions are drawn:

1. Knowledge is a valuable, continuously used strategic resource of a company, it provides competitive advantage and helps to achieve business goals.

2. Knowledge management is a strategic process of organization seeking to develop strategic capabilities, enabling to deal with businesses environmental turbulence and effectively assisting to achieve competitive advantage. 
3. Knowledge management can be defined as a strategy, company culture, organizational learning, systems and technologies interaction with the people, processes and technologies. When this interaction is effective and sustainable, a company can take an advantage of potential benefits of knowledge management.

4. Knowledge management is a multidisciplinary field, which can be analyzed from the perspective of a variety of complementary approaches. A variety of areas and perspectives provides knowledge management advantages, which make it a true company competitiveness-enhancing tool and undermines the proposition that knowledge management resource is useless. In order to create a viable knowledge management system, it is necessary to regulate all aspects of knowledge management harmoniously, depending on the company context.

\section{Practical suggestions and recommendations}

For successful knowledge management initiative during its implementation it is necessary to pay special attention to knowledge management dimensions and knowledge management processes. Responding to the question, how should knowledge management initiative should be implemented, how should it be made successful and provide the company with the competitive advantage, this research designed a knowledge management implementation model, which helps to answer these questions. Knowledge management implementation model suggests, that knowledge management will be successful if the company forms a strategy, which seeks maximum use of knowledge for reaching the goals of the company. Such strategy of the company is forming company culture, which promotes and supports knowledge management. New values are formed to promote knowledge management processes.

Company learning processes also must be associated with processes of knowledge creation, storage, dissemination and use. These learning processes need to be supported by systems and technologies, which become effective and accessible.

All dimensions of knowledge management must be interrelated and focused on a person, who will use them. The concept of knowledge management is closely related to people, managed by people and for people. Disregard of the human factor in the knowledge management process system raises intolerance, that is why it is necessary to make this process close for an individual. In summary we can say, that all of knowledge management factors must be balanced.

To implement the knowledge management system and to get a positive result of it, it is necessary to follow the expediency and measurement principles. Expediency ensures, that knowledge management initiative is introduced for a reason and for a purpose, and based on a specific action plan. Introducing measurement promotes understanding of what is measured. In order to perform accurate measurements, it is necessary to have an exhaustive understanding of what you are measuring. In addition, the company can't manage what can't be measured. Measurement supports resource management. 
This work presents the implementation of knowledge management model, based on expediency and measurement criteria, it can be used as a practical success of knowledge management initiative in the implementation of the template.

\section{References}

Amit, R. and Schoemaker, P. J. H. Strategic assets and organizational rent, Strategic Management Journal, 1993, vol. 14, no. $1,33-46$ p. [interactive] [accessed 04 -06-2013] http:// business .illinois. edu/josephm/BA545_Fall\%202011/ S11/Amit\%20and\%20 Schoemaker\%20 (1993).pdf;

Beniušienè, I. and Svirskienè, G. Konkurencoingums: teorinis aspektas // Ekonomika ir vadyba: aktualijos ir perspektyvos. 2008. Nr. 4(13): 32-40.

Chua, A. and Lam, W. Why KM projects fail: a multi-case analysis // Journal of Knowledge Management, 2005, vol. 9, no. 3, pp. 6-17.

Davenport, Th.H. and Prusak, L. Working Knowledge: How Organizations Manage what They Know. - Boston: Harvard Business School Press, 2000.

Enz, C. A. Hospitality Strategic Management: concepts and cases.New Jersey John Wiley and Sons, 2009.

Fahy, J. and Smithee, A. Strategic marketing and the Resource Based view of the Firm. 1999. - URL.: http:// www.amsreview.org/articles/fahy101999.pdf.

Faucher, Jean-Baptiste et al. Knowledge Management. // Journal of Knowledge Management, 2008, vol. 12, no. 3, pp. 3-16.

Ibrahim, F., Reid,V. Unpacking Knowledge Management: Management Fad or Real Business Practice? Enterprise Risk Management. - North America, 2010.

Jackson, S. E., Hitt, M. A. and DeNisi, A. S.(eds.) Managing knowledge for sustained competitive advantage: designing strategies for effective human resource management: The Organizational Frontiers, 1st edtn, San Francisco: Jossey-Bass, 2003.

Jashapara, A. Knowledge Management: an integrated approach. - Edinburgh: Pearson Education,2004.

Lamb, R. B. Competitive Strategic Management. - Englewood Cliffs, NJ: Prentice Hall, 1984.

Melnikas, B. and Smaliukiene, R, Strateginis valdymas, Mokomoji knyga., Vilnius, Generolo Jono Žemaičio Lietuvos karo akademija, 2007.

Nag, R., Hambrick, D. C. and Chen, J. Ch. What is Strategic Management Really? Inductive Derivation of a Consensus definition of the Field. // Strategic Management Journal, 2007 vol. 28, no. 9, p. 935-955

Newell S., Robertson M, Scarbrough H, Swan J. Managing Knowledge Work. London: Palgrave McMillan, 2002.

Osborne, D. and Gaebler, T. Reinventing Government. - New York: Addison Wesley, Plume 1993.

Porter, M. Competitive Advantage: Creating and Sustaining Superior Performance. - New York: Free Press, 1985.

Porter, M. Competitive Advantage: creating and sustaining superior performance: with a new introduction. - New York: Simon and Schuster, 1998.

Raudeliūnienė, J. Žinių vadyba, Mokomoji knyga. - Vilnius; Technika, 2012.

Savickienè, I., Pukelis, K. Institucinis studijų kokybės vertinimas: dimensijos, 
kriterijai ir rodikliai // Aukštojo mokslo kokybė, 2004, Nr. 1. - p. 26-37.

Shannak, R. O. Measuring Knowledge

Management Performance // European

Journal of Scientific Research. 2009. vol. 35 , no. 2 , - p. 242.
Skyrme, D. J. Knowledge Networking: Creating the Collaborative Enterprise. Oxford: Butterworth-Heinemann, 1999. Thompson, John and Martin Fank. Strategic Management. - London: Cengage Learning, EMEA, 2010.

\title{
ŽINIŲ VADYBOS İTAKOS İMONĖS VEIKLOS EFEKTYVUMUI
}

\author{
Aistė Dromantaitè-Stancikienè, Tatjana Simaškienè \\ Mykolo Romerio universitetas, Lietuva
}

Santrauka. Šiuolaikinèje ekonomikoje, kuriai büdinga verslo imoniu globalizacija ir informacinių technologijų revoliucija, konkurencija atsiskleidžia visais aršumo aspektais. Dél šios „aštrios“ konkurencijos ir konkurentu gebejimo imituoti arba nuplagijuoti apčiuopiamus išteklius, ypatingas dèmesys pradètas skirti nematerialiu ištekliu panaudojimui. Šie ištekliai tapo efektyviais imoniu ginklais, padedančiais igyti konkurencini pranašumą. Jau pora dešimtmečiu visuotinai pripažistama, kad vienas iš svarbiausių imonès nematerialių ištekliu yra žinios.

Straipsnyje analizuojamas žinių valdymo sistemos poveikis įmonès konkurenciniam pranašumui. Sąsajų tarp žiniu vadybos ir konkurencinio pranašumo tyrimas atliekamas per strateginiu valdymu grịsto ištekliu požiūriu prizmę. Analizuojant mokslinę literatūrą, susistemintai pateikiamos žinių ir žinių vadybos sąvokos bei atliekamas jų vertinimas konkurencinio pranašumo atžvilgiu. Siekiant ištirti žiniu vadybos ir konkurencinio pranašumo sąsajas praktineje aplinkoje, buvo pasirinktas kokybinis tyrimo metodas - pusiau standartizuotas interviu. Atliekant surinktu empiriniu duomenu analize pastebèta, kad žiniu valdymas gali padèti pagerinti ìmonès veiklos efektyvuma, dèl ko imonè gali igyti sèkminga konkurencini pranašumą. Tačiau kad žiniu vadybos sistema teiktų nau$d a$, bütina jos kūrimo procese harmoningai derinti visus žinių vadybos aspektus, priklausomai nuo imones veiklos konteksto.

Straipsnio tikslas - praktinèje aplinkoje ištirti žiniu vadybos sąsajas su įmonès konkurenciniu pranašumu, siekiant atskleisti, kaip ir kokiu būdu žiniu vadyba turi ịtakos imonès veiklos efektyvumui bei kaip ji formuoja tvaru konkurencini pranašumą.

Išvados. Straipsniu buvo siekiama praktinejje aplinkoje ištirti žinių vadybos sasajas su įmonès konkurenciniu pranašumu, siekiant atskleisti, kaip ir kokiu būdu žiniu vadyba turi ìtakos imonés veiklos efektyvumui bei kaip ji formuoja tvaru konkurencini pranašumą. Tad išanalizavus interviu metu gautą informaciją, kuri analogiška Jashapara (2004) žinių valdymo metmenims bei žiürint ị surinktus duomenis iš žinių valdymo matmenų atsvaros taško, išryškèja ịrodymai, kurie atskleidžia, kaip žiniu valdymas gali büti naudojamas ịmonès veikloje, siekiant igyti konkurencinį pranašumą. Atlikus tyrimo duomenu analizę ir interpretacija, daromos tokios išvados: 
Žinios yra vertingas, tęstinai ịmonèje naudojamas, strateginis išteklius, suteikiantis konkurencini pranašumą bei padedantis siekti įmonès tikslų.

Remiantis respondentu nuomone, kad žinios yra „didžiausias įmonès turtas“, „informacijos šaltinis apie <...> tai, kaip surasti išmintingus sprendimus“ ir „turtas, padedantis pasiekti konkurencinio pranašumo ir verslo tikslü", galima drasiai tvirtinti, kad žinios yra strateginis išteklius, kuris gali büti naudojamas siekiant konkurencinio pranašumo.

Strategiškai svarbias žinias daro jų unikalumas, jos yra sunkiai imituojamos ir atkartojamos dèl abstrakčios prigimties. Taip pat žinios yra patvarus resursas, saugomas imonés personalo smegenyse arba sistemose, jos gali būti kaupiamos ir naudojamos. Naudojamos jos neišsenka, o priešingai, gausèja. Dar viena žinių savybé - jas sunku pakeisti kitais ištekliais, nes jos yra numanomo pobūdžio.

Tačiau svarbu atkreipti demesį $i$ tai, kad, turédamos potenciala padidinti įmonés konkurencini pranašumą, žinios to neatlieka savaime. Imonè, ketindama pasinaudoti žinių teikiamais privalumais, turi atlikti papildomus parengiamuosius veiksmus.

Žiniu vadyba - ¿̇vairiu sričiu laukas, kurị galima nagrinèti iš įvairių vienas kita papildančiu požiūriu perspektyvų. Sričiu ir perspektyvu ìvairové suteikia žinių vadybai privalumu, kurie ja paverčia puikia ìmonès konkurencinguma didinančia priemone bei paneigia teigini, kad žinių vadybos išteklius yra nenaudingas. Ketinat sukurti gyvybinga žiniu vadybos sistemą, jos kūrimo procese bütina harmoningai derinti visus žiniu vadybos aspektus, priklausomai nuo įmonès veiklos konteksto.

Žiniu vadyba galima apibrèžti kaip strategijos, ịmonès kultūros, organizacinio mokymosi, sistemu bei technologijų sąveika su žmonèmis, procesais ir technologijomis. Kai ši saveika vyksta veiksmingai ir darniai, įmonè gali pasinaudoti potencialia žinių valdymo nauda.

Apibendrinant galima tvirtinti, kad žiniu vadyba - tai organizacijos strateginis procesas, siekiantis kurti strateginius gebejimus, igalinančius kovoti su verslo aplinkos turbulencija ir kuris efektyviausiai padeda pasiekti konkurencinį pranašumą.

Reikšminiai žodžiai: strateginis valdymas, ištekliu požiūris, žinios, žinių vadyba, konkurencinis pranašumas.

Aistė Dromantaitè- Stancikienè, Mykolo Romerio universiteto Politikos ir vadybos fakulteto Vadybos instituto docentè. Mokslinių tyrimų kryptys: karjeros valdymas ir asmeninio gyvenimo balansas, lygios lyčių galimybès, asmeninis augimas (koučingas), pokyčių valdymas, motyvacija ir komunikacija, sprendimų prièmimas.

Aistè Dromantaitė-Stancikienè, Mykolas Romeris University, Faculty of Politics and Management, Institute of Management, Assoc. Professor. Research interests: career management and personal life balance, equal gender opportunities, personal growth (coaching), change management, motivation and communication, decision making. 
Tatjana Simaškienè, Mykolo Romerio universiteto Politikos ir vadybos fakulteto Vadybos magistrantè. Mokslinių tyrimų kryptys: žinių valdymas ir žinių vadyba, strateginis įmonių ir jų išteklių valdymas.

Tatjana Simaškienė, Mykolas Romeris University, Faculty of Politics and Management, Master Student. Research interests: knowledge governance and knowledge management, strategic management of enterprises and resources. 